\title{
Corrigendum
}

Genome Research 27: 393-406 (2017)

Corrigendum: TRUB1 is the predominant pseudouridine synthase acting on mammalian mRNA via a predictable and conserved code

Modi Safra, Ronit Nir, Daneyal Farouq, Ilya Vainberg Slutskin, and Schraga Schwartz

The name of the fourth author was originally misspelled in the author line of this article. Please note the correct spelling as Ilya Vainberg Slutskin. The file has already been corrected online.

doi: $10.1101 /$ gr.225870.117 


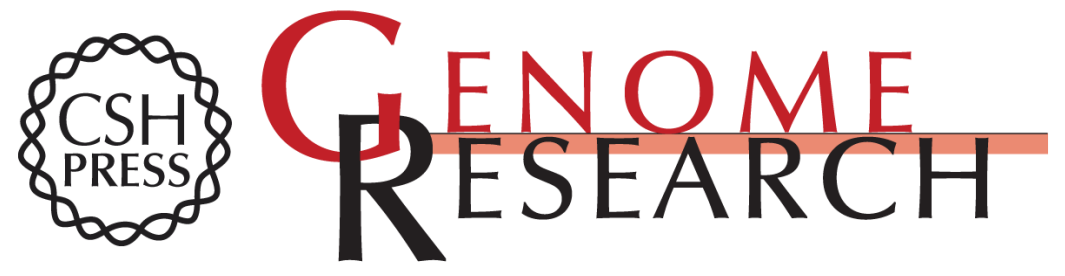

\section{Corrigendum: TRUB1 is the predominant pseudouridine synthase acting on mammalian mRNA via a predictable and conserved code}

Modi Safra, Ronit Nir, Daneyal Farouq, et al.

Genome Res. 2017 27: 1460

Access the most recent version at doi:10.1101/gr.225870.117

Related Content TRUB1 is the predominant pseudouridine synthase acting on mammalian mRNA via a predictable and conserved code

Modi Safra, Ronit Nir, Daneyal Farouq, et al.

Genome Res. March , 2017 27: 393-406

Open Access Freely available online through the Genome Research Open Access option.

License

Email Alerting Receive free email alerts when new articles cite this article - sign up in the box at the Service top right corner of the article or click here.

\section{Affordable, Accurate} Sequencing.

To subscribe to Genome Research go to:

https://genome.cshlp.org/subscriptions 